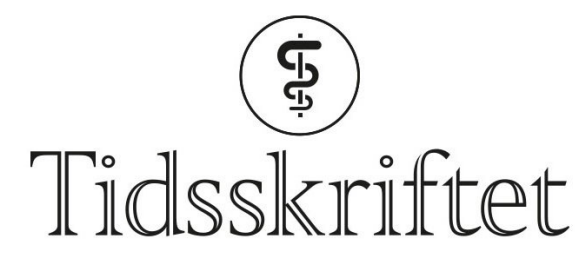

DEN NORSKE LEGEFORENING

\title{
Norske forskere har påvist sykdomsgen
}

FRA ANDRE TIDSSKRIFTER

ØYVIND STOPLE SIVERTSEN

Tidsskriftet

En genvariant som ligger mellom to kodende områder, fører til arvelig ataksi og spastisk paraparese. Det viser en ny norsk studie.

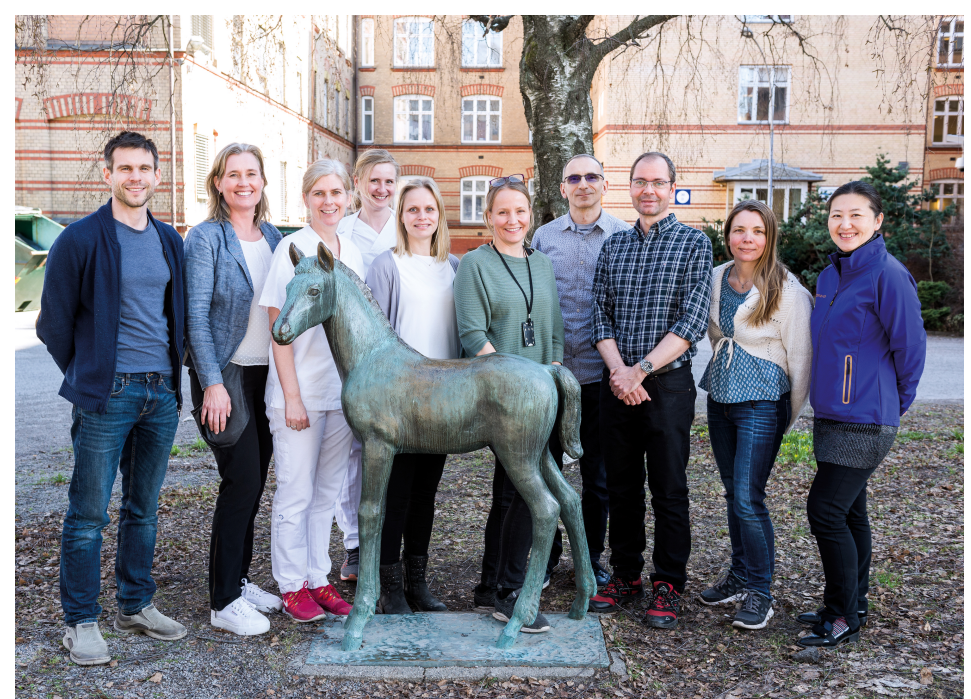

Fra venstre: Magnus Dehli Vigeland, Jeanette Aimee Koht, Anne Kjersti Erichsen, Iselin Marie Wedding, Siri Lynne Rydning, Kaja K. Selmer, Piotr Sowa, Paul H. Backe, Hanne S. Hjorthaug og Ying Sheng. Foto: Øystein Horgmo, Universitetet i Oslo.

Arvelig ataksi og arvelig spastisk paraparese innebærer progredierende gangvansker og bevegelsesforstyrrelser, enten i form av koordinasjonsvansker (ataksi) eller stivhet (spastisitet) i bena. Slike sykdommer er monogene, dvs. at de forårsakes av feil i kun ett gen. Hittil er det beskrevet flere hundre gener som ved genfeil kan forårsake disse tilstandene. Til tross for stadig bedre diagnostiske metoder står fortsatt over halvparten av disse pasientene uten genetisk diagnose. Behandlingen er symptomatisk.

I en studie som nylig er publisert i det prestisjefylte tidsskriftet Brain, har en norsk forskergruppe funnet varianter i genet $P O L_{3} A$ som årsak til arvelig ataksi og spastisk paraparese (1). De unders $\varnothing$ kte eksomet (alt kodende DNA) hos 95 norske familier med arvelig ataksi og/eller spastisk paraparese. 10 familier og 13 pasienter hadde antatt sykdomsforårsakende varianter i dette genet.

Data i studien er hentet fra en database bygget opp av professor emeritus Chantal Tallaksen. 
Denne databasen inneholder opplysninger om flere enn 750 pasienter, inkludert 322 pasienter med mulig recessiv arvegang. Det vil si at selv om ikke alle i denne gruppen er testet, er varianter i POLR3A-genet årsak til sykdom hos minst $3 \% \mathrm{i}$ denne pasientgruppen.

- Et særlig interessant funn om denne nyoppdagede tilstanden er at nesten alle de rapporterte pasientene har den samme genetiske varianten, nemlig en variant som ligger $\mathrm{i}$ et intron, dvs. mellom to kodende områder (eksoner). Denne genvarianten fører til feilaktig spleising av mRNA, slik at proteinet får nedsatt funksjon, sier Siri Lynne Rydning, som er nevrolog, stipendiat og artikkelens førsteforfatter.

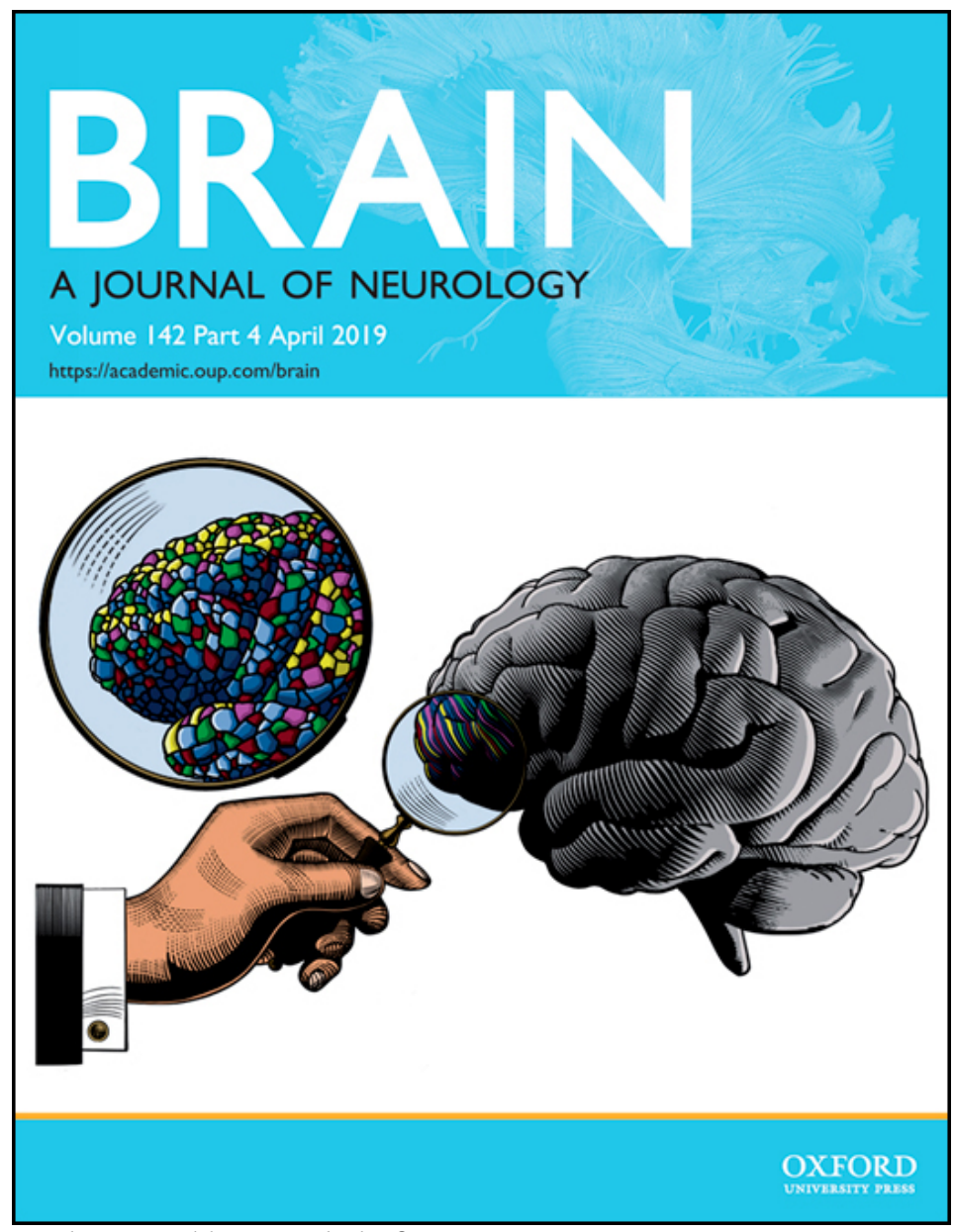

Studien er publisert i tidsskriftet Brain.

- Antagelig er sykdomsmekanismene som gir det svært spesifikke kliniske bildet, knyttet til akkurat denne varianten, sier Rydning.

Funnet illustrerer også hvordan genetiske varianter i ikke-kodende DNA-områder kan forårsake sykdom, noe som understreker viktigheten av å ikke lete etter feil kun i kodende områder.

- Sykdomsmekanismer relatert til feilspleising åpner også for nye innfallsvinkler med tanke på behandling, slik som man for eksempel har sett ved spinal muskelatrofi og bruk av nusinersen, sier Rydning.

POLR3A-relatert sykdom er et eksempel på hvordan varianter i ett og samme gen kan forårsake forskjellige sykdomsbilder, og bidrar til den stadig økende forståelsen av at det kan være felles årsaker og mekanismer bak tilstander som tradisjonelt har vært gruppert i separate "sykdomsbokser».

- For eksempel kan POLR3A-relatert sykdom tenkes å være en differensialdiagnose ved essensiell tremor, som er en mye vanligere tilstand, der alkohol ofte har en tremordempende effekt, sier Rydning.

Studien utgår fra forskningsgruppen for nevrogenetikk ved Avdeling for forskning og 
utvikling ved Nevroklinikken, Oslo universitetssykehus. Lederen for gruppen er Kaja K. Selmer. Gruppens mål er å avdekke genetiske og epigenetiske årsaker og sykdomsmekanismer ved nevrologiske sykdommer, med et hovedfokus på epilepsi, bevegelsesforstyrrelser og muskelskjelettsykdommer. Gruppen består av ph.d.-studenter, masterstudenter og postdok-stipendiater med bakgrunn fra genetikk, nevrologi, cellebiologi og matematikk.

- Vi ønsker å finne genetiske og epigenetiske årsaker til sykdom, sier Rydning.

- Slike funn kan kaste lys på den enkelte sykdom, men også på generelle basale mekanismer i normal fysiologi som er viktig også for andre sykdommer. Det er viktig å sette en molekylær diagnose, da dette kreves for å kunne finne frem til persontilpasset behandling, sier hun.

\section{LITTERATUR:}

1. Rydning SL, Koht J, Sheng Y et al. Biallelic POLR3A variants confirmed as a frequent cause of hereditary ataxia and spastic paraparesis. Brain 2019; 142: e12. [PubMed][CrossRef]

Publisert: 1. august 2019. Tidsskr Nor Legeforen. DOI: 10.4045/tidsskr.19.0402

(C) Tidsskrift for Den norske legeforening 2020. Lastet ned fra tidsskriftet.no 